\title{
Economic Estimation of Woody and Non-Woody Forestry Resources in Present Conditions
}

\author{
Bespalova V.V. \\ S.M. Kirov State Forest Technical University \\ Saint-Petersburg, Russia \\ weronika2002@yandex.ru
}

\author{
Bogatova E.Yu. \\ S.M. Kirov State Forest Technical University \\ Saint-Petersburg, Russia \\ bogatova_25@mail.ru
}

\author{
Filinova I.V. \\ S.M. Kirov State Forest Technical University \\ Saint-Petersburg, Russia \\ filinova_i_v@mail.ru
}

\begin{abstract}
Forestry Code of the Russian Federation provides forests use giving forestry areas with and without forestry resources eliminations.

Economic relations in the sphere of forests use are connected with their charged use. In this case forestry resources and rights of forestry areas use becomes a commodity, the objects of market relations, come into the market of goods in a material form or in a form of services of intravital forest use. The income received after goods realization presents the cost, by means of getting income the principle of charged forests use is realized. Market interest of the owner id getting maximum possible income from his property.

The article considers the questions, connected with forestry resources economic estimation. This question has being discussed in Russia for many decades. Nevertheless, the existing approaches and methods of estimation still have strictly industrial notion: mainly only woody is considered as a dominating part of forestry wealth. Non-woody forestry resources are not included into a resource potential and are not considered as an economic object, which is able to provide additional forestry income.
\end{abstract}

Keywords-economic estimation of forestry resources; woody products; non-woody products; forests renting; effectiveness of foressts use.

\section{INTRODUCTION}

Market relations are realized by means of renting the parts of a forest or in a form of forest range purchase and sale.

Economic effectiveness of forests use first of all should be based on the existing range of criteria in order to estimate this effectiveness.

The criteria of forests economic effectiveness use are the following: general volume of imputed payments for forests use, which should be transferred to federal budget account, the ratio of 1 cubic meter of wood of forest range cutting and payment for the unit of wood volume, real volume of wood production and the stated permitted volume of wood elimination, the volume of forestry fund area, given for rent in general area of forestry fund lands.

The main source of money means into the budget form the payments for forestry resources use, in particular woody resources and the products of forest exploitation. Unfortunately, the products of forest exploitation can't be used practically and the payments for woody resources are so small that they almost can't compensate money spent for their production and protection. There are a lot of ideas directed toward transfer to different methodologies of these payments calculation in order to get bigger income from forests use.

Nowadays in economical science the most objective is the method of payment setting for natural resources use on the basis of rental estimation.

Economists in the sphere of forestry in Russia have already given the range of offers concerning rental approach use during economic estimation of forestry resources and the fee setting.

The approach to rentforming factors consideration during the fee size determination for standing wood offers N.P.Chuprov (doctor of agricultural sciences) [1].

His methodology offers to divide the fee into two parts during its size determination. The first part of general rate for woody resources is determined on the basis of the rent, appears because of forest exploitation conditions inequality. This part of the fee should be set by the methodologies. They are created and adopted for a long time period.

The main condition of the second part of the standing wood rate determination (for forest growing) is the fact that its sum should fully recover the costs of the whole cycle of forest growing, including the cost of forests protection and forest security provision. The first part of the payment should be set on rental basis, the second part is reasonable to calculate, taking into account the demanded expenses for forest management. Rental part of the fee for standing wood is 
offered to set on "forest growing-lumbering-wood reprocessing” stage.

A.P. Petrov offered the methodology of calculating rental payments depending on rentforming factors and the technology of lumbering. On the basis of the received results we can define economically available for exploitation areas and the areas, which are not available in terms of the existing rentforming factors. Forest rent is defined as the difference between the market cost of the final forestry product and the money spent on its production, taking into account normative capital profit provision (cost of production don't include payments for forestry resources). According to this methodology there are two approaches to rental payments formation from the point of view of the final product cost: 1. Product can be in a form of timber, realized in a forest or at lower stock rooms (sawlog, balances, veener log and others); 2. The final product of reprocessing (lumber, cellulose, paper, veneer) [2].

The main principle of modern economics in the sphere of forestry resources use should become the principle of income regulation, received owing to these forestry resources use and the outlays on their keeping and reproduction.

The main kind of use in the forests of Russia is wood production. User tries to get maximum income from forestry area exploitation. Additional financial means can be received from forest exploitation products use. In Russia forest exploitation products include mushrooms, berries, medicinal herbs, barrois, beekeeping, material for getting tanstuff and pigments, materials for wickerwork and other folk artistic crafts, technical material - fatwood, foliage, peeled bark and others. For these additional means getting it is necessary to create methodologies of payments calculation for these products of forest exploitation.

Multiresource management demands special approach to forests control, taking into account multipurpose forest significance. Each forest resource has its own peculiarities of reproduction. Forestry resources are renewable. The outlays on their reproduction should include the outlays on forest growing, protection, forestry management. At the same time, in terms of market economy it is necessary to proportion these outlays with the received money for their use. The payments for using wood are included into the outlays on its formation and the cost of products from wood. Taking into account that in market conditions price is formed under the influence of demand and offer. The level of price for woody products can influence directly the possible level of payments for woody resources.

\section{Research Methodology}

In accordance with its economic essence payment for wood is a rent. It is the return on natural resource, which is formed after wood product realization at market price.

The main way to define the size of the rent in this case should be market prices on final products, which is used by population. During rent calculation final product should be understood as lumber, veneer, plates, paper products, building constructions, furniture. Only at the market of final products, where demand and offer meet, market prices can be formed, which take into account quality and consumption features of forest products, depending on qualitative parameters of forest resources (species, growth class, round wood volume, age of woodland), on one hand and on the other hand consumer demand for this product.

Forest payments formation on the basis of market prices for standing wood is used in the main provinces of Canada.

Market price of timber assortments in Russia should be stated in accordance with private business and state interests. In particular, it should have two marks: maximum mark, which meets the needs of business and minimal mark and meets the needs of the state. At the same time, maximum price limit should be depreciable cost of wood. It is formed if normative expenditures spent on the final products, transport cost and normative income in raw material reprocessing are subtracted from market price of the final product (logging, processing). The low limit of market price would form computations taking into account normative outlays on forest management, protection, forest registration organization. The low limit of price, in contrast with the upper limit, can be accepted in the value same for all timber assortments. For such kind of calculations it is necessary to consider per-process ways of information registration according to each enterprise.

Stating the role of business structure in creating the price of the final product, rent, which takes the form of payments for standing wood, would be defined the following way:

$$
\mathrm{P}=\mathrm{MP} \text { - Cc - PRl - Ctr - PRt, }
$$

where P- payments for standing wood, MP-market price of a round wood, Cc- round wood logging cost, PRl-income from round wood logging, Ctr - transportation cost, PRt income on transporting.

Payments for standing wood should correspond with the forest renewal costs, is protection.

$$
\mathrm{P} \geq \mathrm{Z}
$$

where $\mathrm{Z}$ - forest renewal and protection costs.

\section{RESULTS}

Market prices for the wood product are stated on the basis of market prices analysis in home and export market of Russia. They depend on stand of timber diameter and species of wood.

A businessman in Russia, renting forest areas should understand the effectiveness degree of wood logging, taking into account species of wood, size and qualitative characteristics.

During payment determination for standing wood it is necessary to take into account the factors, which influence both logging costs and income from its use. These factors would influence the volume of this payment. These factors include: round wood volume, the distance of prepared timber stand removal, wood stock for 1 ha., species composition of wood. It is possible to consider these factors influence through the structure of costs and price (Table 1). 
Table IV presents coefficients, which show

TABLE I. THE INFLUENCE OF FACTORS ON INCOME AND OUTLAY ON ROUND WOOD MATERIALS LOGGING

\begin{tabular}{|c|c|c|}
\hline Factors & $\begin{array}{c}\text { Income (the price of } \\
\text { round wood materials) }\end{array}$ & $\begin{array}{c}\text { Expenditures connected } \\
\text { with round wood } \\
\text { materials logging }\end{array}$ \\
\hline Round wood volume & + & + \\
\hline Distance of removal & & + \\
\hline Wood stock for 1 ha. & + & + \\
\hline Species & + & + \\
\hline
\end{tabular}

During payment calculation given for standing wood we considered thoroughly outlays on round wood logging, which are included in formula 1 . We revealed costs change dependence on the factors, presented in Table II.

We know that during the round wood volume increase separate elements of outlays on round wood logging (such as, wages, petrol expenditure) decrease and lead to total outlays sum decrease. In order to prove it we held the research using project models method.

We calculated coefficient, which characterize outlays change on logging from round wood volume (table II).

TABLE II. COEFFICIENTS, WHICH CHARACTERIZE OUTLAYS CHANGE ON LOGGING 1 CUBIC METER FROM ROUND WOOD VOLUME

\begin{tabular}{|c|c|c|c|c|c|c|c|}
\hline $\begin{array}{c}\text { Round wood } \\
\text { volume, } \mathrm{m} 3\end{array}$ & $\begin{array}{c}0,14- \\
0,17\end{array}$ & $\begin{array}{c}0,18- \\
0,21\end{array}$ & $\begin{array}{c}0,22- \\
0,29\end{array}$ & $\begin{array}{c}0,3- \\
0,39\end{array}$ & $\begin{array}{c}0,4- \\
0,49\end{array}$ & $\begin{array}{c}0,5- \\
0,75\end{array}$ & $\begin{array}{c}0,76- \\
1,10\end{array}$ \\
\hline Coefficient & 1,0 & 0,94 & 0,80 & 0,73 & 0,67 & 0,62 & 0,60 \\
\hline
\end{tabular}

Taking into account the received coefficients we come to the following conclusion: outlays on $1 \mathrm{~m} 3$ of wood logging with round wood volume $0,82 \mathrm{~m} 3$ are $60 \%$ lower, than outlays on $1 \mathrm{~m} 3$ of wood logging with round wood volume 0,16 m3.It means that outlays on logging $1 \mathrm{~m} 3$ of wood decrease during bigger trees cutting.

The volume of wood stock on 1 ha territory also influences outlays on wood logging. As a result of the research we received the following coefficients of this influence (Table III).

TABLE III. COEFFICIENTS, WHICH TAKE INTO ACCOUNT WOOD STOCK ON 1 HA AREA

\begin{tabular}{|c|c|}
\hline $\begin{array}{c}\text { The average stock of wood on } 1 \text { ha } \\
\text { area, m3 }\end{array}$ & Coefficient \\
\hline $51-75$ & 1,0 \\
\hline $76-100$ & 0,92 \\
\hline $101-125$ & 0,86 \\
\hline $126-150$ & 0,83 \\
\hline $151-175$ & 0,81 \\
\hline $176-200$ & 0,78 \\
\hline $201-250$ & 0,77 \\
\hline
\end{tabular}

interconnection of removal distance with the outlays on round wood logging.

TABLE IV. COEFFICIENTS, WHICH TAKE INTO CONSIDERATION REMOVAL DISTANCE

\begin{tabular}{|c|c|}
\hline The average removal distance, $\mathrm{km}$ & Coefficient \\
\hline 20 & 1,0 \\
\hline 30 & 1,24 \\
\hline 40 & 1,49 \\
\hline 50 & 1,70 \\
\hline 60 & 1,89 \\
\hline 70 & 2,11 \\
\hline 80 & 2,27 \\
\hline 90 & 2,51 \\
\hline 100 & 2,70 \\
\hline
\end{tabular}

Using received coefficients it is possible to calculate outlays on wood logging and payments for the used wood [3].

Modern forestry relations, the demands increase placed on effectiveness of forest use should change the attitude to nonwoody products as a valuable part of market relations, which causes demand and offer, but not as a "worthless product".

However, nowadays there are no main principles of forestry relations in the sphere of non-woody forest resources use, no adopted methodology of payment size determination for use, no information about the outlays on reproduction, no system of effectiveness indices of forest resources use in particular and in general. New research works in this sphere would help to solve complex of problems: to reveal economically attractive lands for logging, define effectiveness of different resources use, substantiate alternative use of forest lands, estimate the effectiveness of forestry events, stimulate complex use of forest resources [4].

According to statistics within last 10 years 2008-2018 the income form forest areas rent, connected with accessory use realization, in the Russian Federation was not more than 1-2\% from the received federal budget means.

Nevertheless, nowadays we have a successful experience of some region of Russia (Far East, Volgograd region, Pskov region, Jewish Autonomous Region), where the role of accessory wood exploitation during recent years increased and became economically profitable and significant. However, it is mainly provided owing to high level of economic effectiveness of non-woody products export. It is conditioned by considerable difference between inner world prices for the same products. Though, the level of world prices mainly depends on purchasing power of developed European countries population, not on the merits of exporters-producers, that is why exporters should have only normative level of income on the invested capital [5]. If superprofit, which is rent taken at a state border, would be given as forest income to the budgets of all levels, it would provide more complete financing of forestry and forest protecting events, directed 


\section{References}

and protection [6].

\section{IV.CONCLUSION}

In the opinion of the authors, payments for non-woody resources use should be taken not only during lease agreement formation, but also during renting relations formation for wood logging. The research works prove that industrial harvestings decrease the areas of berry-fields, the regime of illumination changes and mushrooms start to fruit in 25-30 years, the migration of animals starts. As a result, such nonwoody resources elimination should be compensated by rent increase including "lost benefit" for non-woody forest resources and future outlays on their renewal. Such kind of mechanism would help to provide balance of all forest relations subjects' interests.

[1] Chuprov N.P. "About the methodology of economic estimation and availability of woody resources of forest”. Forest magazine. - 2004; №6: 103-108

[2] Petrov A.P. "Rent as an effective mechanism of wood exploitation income increase”. Natural resources use and protection in Russia. - 2002; №3: 82-84

[3] Bespalova V.V., Kadyrova O.V. "The practice of rent formation analysis for forest use”. Bulletin of management faculty of Saint-Petersburg State Economic University. 2018; № 3: 15-19.

[4] Samsonova I., Gryazkin A., Belyaeva N., Bespalova V., Lyubimov A., Belyaev V., Petrik V. Nature-oriented potential resource and melliferous value of forest belts in steppe agro-forest landscapes. Folia Forestalia Polonica, Series A. 2018. Volume 60. № 2: 99-107.

[5] Bogatova E.Yu. Analysis of payment for forests use by the example of foreign countries with an intensive use of forest resources. Bulletin of Economics and management Institute of Novgorod state named after Yaroslav Mudryi. 2014; № 2: 39-43.

[6] Alexsandr S. Kuznetsov. Russian Professor's meeting. Russian Journal of Physical Education and Sport. 2019, 14(1), pp. 17-22. DOI: 10.14526/2070-4798-2019-14-1-18-24 